\title{
Antimicrobial activity and safety evaluation of peptides isolated from the hemoglobin of chickens
}

\author{
Fengjiao Hu', Qiaoxing Wu', Shuang Song ${ }^{1}$, Ruiping She ${ }^{1 *}$ (D), Yue Zhao ${ }^{1}$, Yifei Yang ${ }^{1}$, Meikun Zhang ${ }^{2}$, Fang Du', \\ Majid Hussain Soomro ${ }^{1}$ and Ruihan Shi ${ }^{1}$
}

\begin{abstract}
Background: Hemoglobin is a rich source of biological peptides. As a byproduct and even wastewater of poultryslaughtering facilities, chicken blood is one of the most abundant source of hemoglobin.

Results: In this study, the chicken hemoglobin antimicrobial peptides (CHAP) were isolated and the antimicrobial and bactericidal activities were tested by the agarose diffusion assay, minimum inhibitory concentration (MIC) analysis, minimal bactericidal concentration (MBC) analysis, and time-dependent inhibitory and bactericidal assays. The results demonstrated that CHAP had potent and rapid antimicrobial activity against 19 bacterial strains, including 9 multidrug-resistant bacterial strains. Bacterial biofilm and $\mathrm{NaCl}$ permeability assays, transmission electron microscopy (TEM) and scanning electron microscopy (SEM) were further performed to detect the mechanism of its antimicrobial effect. Additionally, CHAP showed low hemolytic activity, embryo toxicity, and high stability in different temperatures and animal plasma.
\end{abstract}

Conclusion: CHAP may have great potential for expanding production and development value in animal medication, the breeding industry and environment protection.

Keywords: Antimicrobial peptides, Hemoglobin, Hydrolysis, Antimicrobial activity, Bactericidal activity

\section{Background}

Due to the widespread use and even abuse of conventional antibiotics, antibiotic resistance is rampant all over the world, which limits the lifespan of commercial antibiotics and results in the urgent demand of new platforms for efficient antibiotic discovery [1,2].

As an essential part of innate immunity, antimicrobial peptides (AMPs) have been receiving increasing attention because of their unique antimicrobial mechanism against both Gram-positive and Gram-negative bacteria, and even including some multidrug-resistant strains over recent decades $[3,4]$. Antimicrobial peptides are ubiquitous in all living organisms. More than 5000 AMPs (http://www.camp.bicnirrh.res.in/index.php) have been identified and 2593 peptides have been derived naturally

\footnotetext{
* Correspondence: sheruiping@126.com

1Department of Veterinary Pathology and Public Health, Key Laboratory of Zoonosis of Ministry of Agriculture College of Veterinary Medicine, China Agricultural University, Beijing 100193, China

Full list of author information is available at the end of the article
}

(http://aps.unmc.edu/AP/main.php) since the discovery of the lysozyme by Alexander Fleming in 1922 [5]. Although substantial AMPs have been discovered over the past decades, only a small part of them have been used because of high costs and potential cytotoxicity $[1,6]$. Hence, finding efficient, nontoxic and low-cost AMPs is urgent in promoting AMPs' practical applications.

The whole blood is a mixture of cells (erythrocytes, leucocytes and platelets) and plasma (colloids and crystalloids), which delivers nourishment and oxygen to and removes waste products from all parts of the body [7]. Components in blood, such as platelet concentrates [8], defensins [3], leukocyte extracts [9], also play important roles in antimicrobial host defense. Hemoglobin is the main component of the erythrocyte [10]. Aside from the basic function of transporting oxygen, hemoglobin has been found as a source of various biological peptides [11-13]. Many AMPs called hemocidins have been isolated from hemoglobin cleavage in vivo [14] or from 
hemoglobin hydrolysis by chemical reagents, physical methods, or enzymes in vitro $[15,16]$. To date, the hemocidins derived from human beings [17], bovines [12], rabbits [18], swine [15], crocodiles [19], fish [20], and shellfish [21] have been reported and most of them are made up of 2 to 60 residues, characterized by a common random coil structural and broad-spectrum antimicrobial activity [22-24]. As a byproduct and even one of the major dissolved pollutants in slaughter house wastewater [25], appropriate treatment of chicken blood is of great benefit to both environmental protection and economic development. However, hemocidins from poultry have not been documented yet. In this study, the hemocidins from chickens were isolated and their antimicrobial and bactericidal activities were further detected.

\section{Methods}

\section{Materials and chemicals}

All common chemical reagents and biological products were of analytical grade from commercial sources. Papain (2000 IU g ${ }^{-1}$ ) was purchased from Sigma Chemical Co. (St. Louis, Mo, America).

\section{Preparation of CHAP}

The chicken hemoglobin antimicrobial peptides (CHAP) were prepared as modified method described before [26]. In brief, fresh chicken blood (Beijing Huadu Broiler Corporations, Beijing, China) was collected with heparin and then centrifuged with $2,000 \times g$ at $4{ }^{\circ} \mathrm{C}$ for $10 \mathrm{~min}$. The upper liquid and white cells were removed and washed with sterilized saline. The procedures described above were repeated 3 times. The cells were frozen, thawed, stirred and homogenized in deionized water (pH 7.0) with papain $(1: 1,000 \mathrm{w} / \mathrm{v})$ proteolysis at $70{ }^{\circ} \mathrm{C}$ for $8 \mathrm{~h}$. The digested suspensions were added with icecold aqueous $5 \%$ acetic acid solution $(1: 1 \mathrm{v} / \mathrm{v})$ and extracted overnight at $4{ }^{\circ} \mathrm{C}$. After being centrifuged at $8,000 \times g$ for $30 \mathrm{~min}$ at $4{ }^{\circ} \mathrm{C}$, the suspensions were collected as crude extracts, and the protein concentration was detected by NanoDrop 2000 UV-vis Spectrophotometer (Thermo Fisher Scientific, Massachusetts, America). The $\mathrm{pH}$ of the extracts was adjusted to 6.0 with sodium hydroxide. The crude extracts were loaded onto $10 \times 300 \mathrm{~mm}$ Sephadex G-100 column and eluted by $0.2 \mathrm{~mol} \mathrm{~L}^{-1}$ sodium acetate buffer ( $\left.\mathrm{pH} 6.0\right)$ with the speed of $12.0 \mathrm{~mL} \mathrm{~cm}^{-2} \mathrm{~h}^{-1}$ Each elution was analyzed by agarose diffusion assay [27] with Escherichia coli ATCC 25922 as the indicator organism. The fractions with potent antibacterial activity were collected and detected with Tricine SDS-PAGE [28] and then subjected to mass spectrometry (Beijing Protein Innovation Co., Ltd., Beijing, China).
Bacterial strains and growth conditions

Staphylococcus aureus ATCC25923, Staphylococcus aureus ATCC 29213, Staphylococcus albus ATCC01331, Escherichia coli ATCC 25922, Escherichia coli O78, Escherichia coli C83922, Escherichia coli C83901, Pseudomonas aeruginosa ATCC27853, Pasteurellae gallinarum C48-3 were purchased from the China Veterinary Culture Collection Center (CVCC). Aeromonas hydrophila, Bacillus cereus and Escherichia coli were clinically isolated from crucian carps, pigeon and equines respectively by Laboratory of Veterinary Pathology and Public Health of the College of Veterinary Medicine, China Agricultural University. Staphylococcus aureus MR-L22, MR-QD-CD10, Enterococcus faecalis 53A, 52A, $37 \mathrm{~N}$ and Pseudomonas aeruginosa M140 and Escherichia coli T50 were all multi-resistance strains of clinics, and obtained from Beijing Key Laboratory of Detection Technology for Animal Food safety of the College of Veterinary Medicine. All the above Gram-negative strains were grown in Luria-Bertani (LB) agar and the Gram-positive bacteria were grown in brain heart infusion (BHI) agar.

\section{Determination of antimicrobial and bactericidal activities Agarose diffusion assay}

The primary antibacterial activities of CHAP elution $\left(100 \mu \mathrm{g} \mathrm{mL}^{-1}\right)$ were detected by modified agarose diffusion assay as described before [27]. Briefly, the single colony of each bacterial strain was grown in trypticase soy broth (TSB, $30 \mathrm{~g} \mathrm{~L}^{-1}$ ) overnight at $37^{\circ} \mathrm{C}$ under aer-

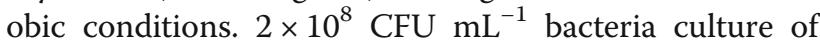
each strain was added to warm $\left(50-55{ }^{\circ} \mathrm{C}\right)$ sterile agarose [1\% agarose (low EEO, Sigma, St. Louis, MO), 0.03\% nutrient broth, and $10 \mathrm{mM}$ PBS buffer, $\mathrm{pH}$ 7.4] $(1: 100 \mathrm{v} / \mathrm{v})$. $10 \mu \mathrm{L}$ samples were added to $3 \mathrm{~mm}$ wells punched by agar punch (BioRad Laboratories, Hercules, Canda). $0.2 \mathrm{~mol} \mathrm{~L}^{-1}$ sodium acetate (solvent) and 20000 IU penicillin-streptomycin solution of the same volume were added as negative and positive control, respectively. After being incubated overnight at $37{ }^{\circ} \mathrm{C}$, the diameter of the each clean zone of growth inhibition was measured as the antibacterial activity of CHAP against different strains.

\section{Minimum inhibitory concentration (MIC) analysis}

A micro dilution assay was employed to determine MIC according to the broth micro dilution guideline of Clinical and Laboratory Standards Institute (CLSI) [29]. Briefly, $50 \mu \mathrm{L}$ of twofold serial dilutions of CHAP (25 to $0.20 \mu \mathrm{g} \mathrm{mL}{ }^{-1}$ ) was placed into wells of sterile 96-well cell culture plates. The $50 \mu \mathrm{L}$ of bacterial suspensions $\left(1 \times 10^{5} \mathrm{CFU} \mathrm{mL}^{-1}\right)$ were added to the peptides. The wells were added with $50 \mu \mathrm{L}$ of Mueller- Hinto (MH) broth and $50 \mu \mathrm{L}$ of bacterial culture was treated as 
positive and negative control, respectively. After $24 \mathrm{~h}$ incubation, the MICs were determined at $492 \mathrm{~nm}$ by spectrophotometer (Thermo Multiskan MK3, Thermo Fisher Scientific, Massachusetts, America).

\section{Time-dependent inhibitory assay}

A $500 \mu \mathrm{L}$ aliquot of CHAP with $2 \times$ MIC of the bacterium was added respectively to $500 \mu \mathrm{L}$ bacterial suspensions $\left(1 \times 10^{5} \mathrm{CFU} \mathrm{mL}{ }^{-1}\right)$ in the sterilized $1.5 \mathrm{~mL}$ tubes as the treated groups. Bacteria treated with $500 \mu \mathrm{L}$ solvent $\left(0.2 \mathrm{~mol} \mathrm{~L}^{-1}\right.$ sodium acetate) were set as the control groups. After being incubated for $30 \mathrm{~min}, 100 \mu \mathrm{L}$ aliquot of the suspensions were pipetted into to a sterilized $1.5 \mathrm{~mL}$ tube. After centrifugation at $1,000 \times g$ for $5 \mathrm{~min}$, the supernatant was removed, and the pellet was resuspended in $100 \mu \mathrm{L}$ MHB medium. Tenfold serially diluted suspension was placed on agar plates and incubated at $37{ }^{\circ} \mathrm{C}$ until viable colonies could be seen and the numbers of colony-forming units (CFU) were counted. The inhibitory rate of each bacterium was calculated according to the following formula: the inhibitory rate $=[($ colonies of the treated group - colonies of the treated group)/colonies of the control group] $\times 100 \%$.

In order to further detect the process and speed of the antimicrobial activity of CHAP, the time growth curves and inhibitory rates of Escherichia coli ATCC 25922, Staphylococcus aureus ATCC29213, Staphylococcus aureus MR-L22, Enterococcus faecalis 52A, Pseudomonas aeruginoda M140 and Escherichia coli T50 were achieved after the treated suspensions were incubated for $0,5,10,30,90 \mathrm{~min}$ respectively.

\section{Minimal bactericidal concentration (MBC) analysis}

The MBC values were determined in 96-well plates, which was similar to the method of MIC. MBC values were further confirmed by plating $100 \mu \mathrm{L}$ samples of each well with no visible turbidity onto the MHB medium. The least concentration showing no visible growth on the plates was considered as the $\mathrm{MBC}$ value.

\section{Time-dependent bactericidal assay}

The time depending bactericidal curves of Escherichia coli ATCC 25922 were determined as the timedependent inhibitory assay mentioned above by adding CHAP with concentration of its $\mathrm{MBC}$ value to the bacterial cultures grown to early and late exponential phase as the reference [2].

In order to detect the bacteriolysis against bacteria in stationary phase, $10 \mathrm{ml}$ of bacterial culture $\left(2 \times 10^{9}\right.$

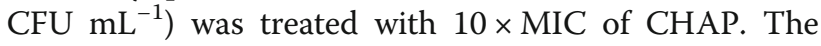
culture treated with solvent $\left(0.2 \mathrm{~mol} \mathrm{~L}^{-1}\right.$ sodium acetate $)$ was set as the control group. After $24 \mathrm{~h}$ incubation, $2 \mathrm{ml}$ of each culture was added to a glass tube and was photographed [2].

\section{Bacterial biofilms assay}

Crystal violet staining method was applied to detect the effect of CHAP on the biofilm formation [30]. Briefly, Staphylococcus aureus ATCC29213 were cultured in TSB overnight. $100 \mu \mathrm{L}$ bacterial suspensions $\left(1 \times 10^{6} \mathrm{CFU} \mathrm{\textrm {mL } ^ { - 1 } )}\right.$ with $2 \times \mathrm{MIC}, 1 \times \mathrm{MIC}, 1 / 2 \times$ MIC, $1 / 4 \times$ MIC, $1 / 8 \times$ MIC, $1 / 16 \times$ MIC of CHAP were added to 96 -well plates and the bacterial suspensions with no CHAP and the sterilized TSB were treated as control groups. After static culture at $37{ }^{\circ} \mathrm{C}$ for $24 \mathrm{~h}$ or shake culture $(50 \mathrm{rmp})$ at $37{ }^{\circ} \mathrm{C}$ for $72 \mathrm{~h}$, the contents were aspirated and the wells were washed by $200 \mu \mathrm{L}$ PBS for three times, methanol fixed for $1 \mathrm{~h}$ and stained with $200 \mu \mathrm{L}$ crystal violet $\left(5 \mathrm{~g} \mathrm{~L}^{-1}\right)$ for $30 \mathrm{~min}$. The wells were washed by running water and air dried. The plates were determined at $600 \mathrm{~nm}$ by spectrophotometer.

\section{$\mathrm{NaCl}$ permeability assay}

The effect of CHAP on the $\mathrm{NaCl}$ permeability of bacteria was detected as modified protocol as follows [31]. $100 \mu \mathrm{L}$ of bacterial suspensions $\left(1 \times 10^{6} \mathrm{CFU} \mathrm{mL}^{-1}\right)$ with $1 / 2 \times$ MIC of CHAP were added to 96-well plates and the bacterial suspensions with no CHAP as control. $100 \mu \mathrm{L}$ of $\mathrm{NaCl}$ solutions with different concentrations $\left(80,100,120,140,160,180,200 \mathrm{~g} \mathrm{~L}^{-1}\right)$ were added into each wells and incubated at $37^{\circ} \mathrm{C}$ for $12 \mathrm{~h}$. The bacterial concentration of each well was determined by measuring the optical density at $600 \mathrm{~nm}\left(\mathrm{OD}_{600}\right)$.

\section{Electron microscopy observations}

Both transmission electron microscopy (TEM) and scanning electron microscopy (SEM) were conducted as previously described [32-34]. Briefly, Escherichia coli ATCC 25922 and Staphylococcus aureus ATCC29213 were cultured overnight, $10^{7} \mathrm{CFU} \mathrm{ml}{ }^{-1}$ bacteria were incubated with $1 \times$ MIC of CHAP or diluents of the same volume at $37^{\circ} \mathrm{C}$ for $30 \mathrm{~min}$. All the samples were fixed and proceeded for the TEM and SEM respectively.

\section{Hemolytic assay and embryotoxicity assay}

The hemolytic activity was evaluated as previously described [35]. 4\% (vol/vol) fresh chicken erythrocyte suspensions were added to a 96-well plate and incubated with CHAP at 360, 180, 90, 45, 22.5, $11.25 \mu \mathrm{g} \mathrm{mL}^{-1}$ individually at $37^{\circ} \mathrm{C}$ for $1 \mathrm{~h}$. Wells treated with PBS and $0.1 \%$ Triton $\mathrm{X}-100$ of the same volume were taken as 0 and $100 \%$ hemolysis. The wells were determined by measuring the optical density at $492 \mathrm{~nm}\left(\mathrm{OD}_{492}\right)$.

The embryotoxicity of CHAP was detected as the following measures. The 10-days-old-chicken embryos were randomly divided into 5 groups, each of 10 eggs, $0.2 \mathrm{~mL}$ of CHAP of $1 \times \mathrm{MIC}, 2 \times \mathrm{MIC}, 4 \times \mathrm{MIC}, 6 \times \mathrm{MIC}$ dose against Escherichia coli ATCC25922 were injected 
into the chorio-allantoic cavity, and embryos treated with the same volume of solvent $\left(0.2 \mathrm{~mol} \mathrm{~L}^{-1}\right.$ sodium acetate) were used as controls. The eggs were put in a hatching machine and hatchability and weight of the eggs were observed regularly until hatching.

\section{Stability in different temperatures and in $\mathbf{5 0 \%}$ plasma} CHAP $\left(100 \mu \mathrm{g} \mathrm{mL}^{-1}\right)$ was treated with different temperatures varying from $30{ }^{\circ} \mathrm{C}, 40{ }^{\circ} \mathrm{C}, 50{ }^{\circ} \mathrm{C}, 60{ }^{\circ} \mathrm{C}, 70{ }^{\circ} \mathrm{C}$, $80{ }^{\circ} \mathrm{C}, 90{ }^{\circ} \mathrm{C}, 100{ }^{\circ} \mathrm{C}, 121{ }^{\circ} \mathrm{C}$ for $30 \mathrm{~min}$. The antimicrobial activities of these treated aliquots were determined with agarose diffusion assay and were compared with CHAP stored in $4{ }^{\circ} \mathrm{C}$.

The stability of CHAP in 50\% plasma was evaluated as previously described [29] with some modifications. Briefly, the plasma of chicken and rabbit was determined with no antimicrobial activity before the test. Then $640 \mu \mathrm{g} \mathrm{ml}^{-1} \mathrm{CHAP}$ was diluted 1:1 in fresh chicken and rabbit plasma and pre-incubated at $37{ }^{\circ} \mathrm{C}$ for 0,3 , and $6 \mathrm{~h}$ respectively. After incubation, the antimicrobial activity of each sample was determined by agarose diffusion assay. The effect of CHAP diluted by its solvent was regarded as the $100 \%$, and the effect of the treated samples was demonstrated as percentages.

\section{Statistical Analysis}

Experiments were conducted with biological replicates and experimental data were expressed as mean \pm standard deviation of at least three determinations and analyzed by one-way ANOVA using SPSS 20.0 (SPSS Inc., Cary, NC, USA). Differences were considered to be statistically significant at $P<0.05$ or $P<0.01$.

\section{Results}

\section{Preparation of CHAP}

The crude extracts of CHAP were light yellow and the protein concentration was adjusted to $5 \mathrm{mg} \mathrm{ml}^{-1}$ before loading on the Sephadex G-100 column. There were two main peaks after the elution of Sephadex G-100 gelatin (Fig. 1a) and the tubes from 9 to 16 in the left half of the second peak showed potent antimicrobial activity (Fig. 1b). Detected by Tricine SDS -PAGE, the collected CHAP showed band around $3.3 \mathrm{KDa}$ (Fig. 1c). This band was further analyzed and peptides of gallus hemoglobin subunit alpha were confirmed by mass spectrum (see Additional file 1).

\section{Determination of antimicrobial and bactericidal activity Antimicrobial effect of CHAP}

The results of antibacterial activity of CHAP detected via agarose diffusion assay, MIC assay and inhibitory rate assay are shown in the columns $2-4$ in Table 1.These results demonstrated that CHAP performed potent antimicrobial activities against both Gram-negative bacteria and Gram-positive bacteria, including 9 multidrugresistant strains.

The time-dependent growth inhibitory activities of CHAP are shown in Fig. 2a-d. The results showed that CHAP not only significantly inhibited the growth of standard strains $(P<0.05)$, but also effectively inhibited the multi-resistant ones $(P<0.05)$ in $10 \mathrm{~min}($ Fig. $2 \mathrm{a}$ and b). The inhibitory rates of all six strains reached $100 \%$ in 90 min (Fig. 2c and d). Although there were different growth inhibitory curves, CHAP showed more than 50\% inhibitory rate against all six strains in $10 \mathrm{~min}$.

\section{Bactericidal effect of CHAP}

The values of MBC are shown in column 5 of Table 1. By analyzing the values, most bacteria were killed by CHAP at concentrations ranging from $5 \mu \mathrm{g} \mathrm{m}^{-1}$ to $80 \mu \mathrm{g} \mathrm{mL}{ }^{-1}$. However, 7 strains showed no obvious bactericidal effect with the maximum concentration of $160 \mu \mathrm{g} \mathrm{mL}{ }^{-1}$. The time-dependent bactericidal curves in Fig. $2 \mathrm{e}$ and $\mathrm{f}$ further revealed that the significant bactericidal effect of CHAP on both the bacteria grown to early and late exponential phases from $10-240 \mathrm{~min}(P<0.01)$.

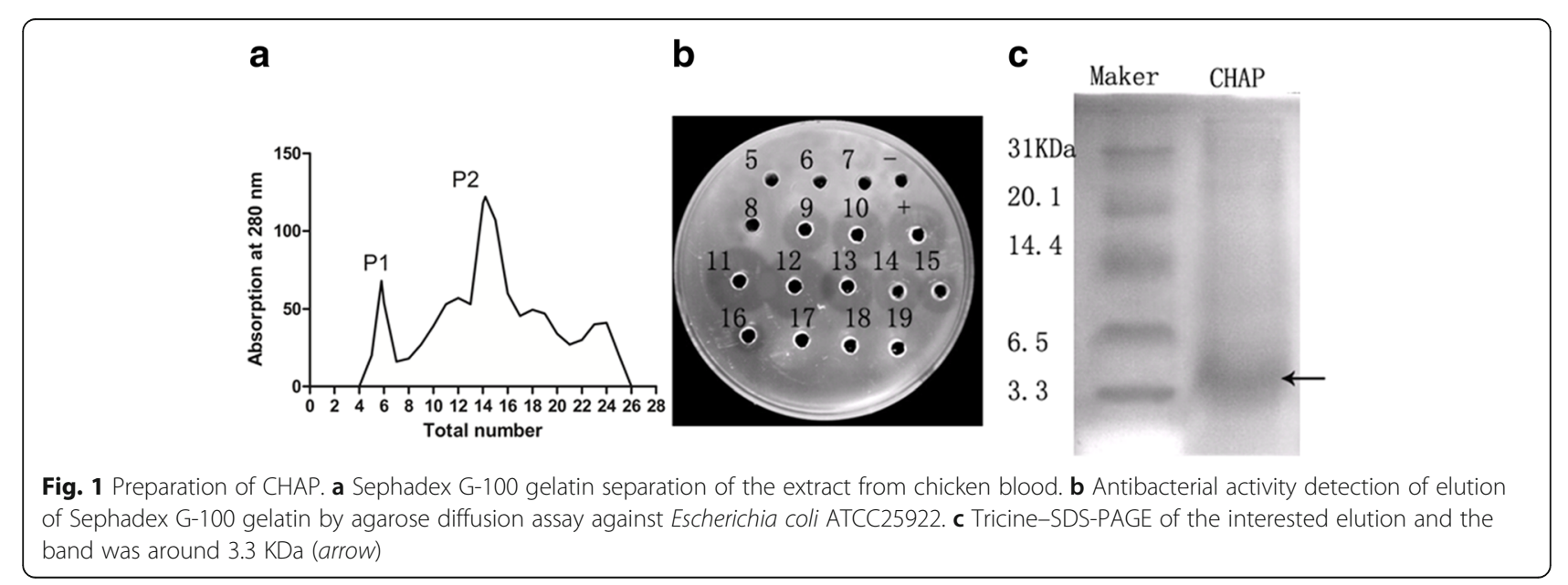


Table 1 Antibacterial activity and bactericidal activity of Chicken hemoglobin fragment peptides

\begin{tabular}{|c|c|c|c|c|}
\hline Strains & $\mathrm{D}(\mathrm{mm})$ & MIC $\left(\mu \mathrm{g} \mathrm{mL}^{-1}\right)$ & IR (\%) & $\mathrm{MBC}\left(\mu \mathrm{g} \mathrm{mL}^{-1}\right)$ \\
\hline \multicolumn{5}{|l|}{ Gram-negative bacteria } \\
\hline Escherichia coli ATCC 25922 & 24.5 & 6.25 & 83.00 & 80 \\
\hline Escherichia coli C83901 & 18 & 12.5 & 66.53 & 80 \\
\hline Escherichia coli C83922, & 20 & 6.25 & 55.24 & 80 \\
\hline Escherichia coli O78 & 18 & 6.25 & 47.83 & 80 \\
\hline Aeromonas hydrophila(crucian carp) & 13 & 3.13 & 52.05 & $>160$ \\
\hline Pseudomonas aeruginosa ATCC27853 & 15 & 3.13 & 52.94 & 80 \\
\hline Pasteurellae gallinarum C48-3 & 12 & 3.13 & 63.63 & 80 \\
\hline MR- Escherichia coli(equine) & 33.5 & 6.25 & 62.73 & 80 \\
\hline MR- Pseudomonas aeruginosa M140 & 19 & 1.56 & 85.56 & 5 \\
\hline MR- Escherichia coli T50(swine) & 11 & 6.25 & 89.92 & 80 \\
\hline \multicolumn{5}{|l|}{ Gram-positive bacteria } \\
\hline Staphylococcus aureus ATCC25923 & 27 & 3.13 & 50.00 & $>160$ \\
\hline Staphylococcus aureus ATCC 29213 & 21 & 3.13 & 94.26 & 5 \\
\hline Staphylococcus albus ATCC01331 & 14.5 & 1.56 & 73.36 & 40 \\
\hline MR-Bacillus cereus (pigeon) & 13.5 & 3.13 & 73.36 & 20 \\
\hline MR-Staphylococcus aureus L22(swine) & 15.5 & 6.25 & 88.6 & $>160$ \\
\hline MR-Staphylococcus aureus QD-CD10 (swine) & 15.5 & 6.25 & 56.93 & $>160$ \\
\hline MR-Enterococcus faecalis 53A(pet) & 22 & 1.56 & 91.10 & $>160$ \\
\hline MR-Enterococcus faecalis 52A(pet) & 13.5 & 6.25 & 35.00 & $>160$ \\
\hline MR-Enterococcus faecalis $37 \mathrm{~N}$ (pet) & 29 & 3.13 & 55.00 & $>160$ \\
\hline
\end{tabular}

$M R$ multidrug resistance (in bold), $D$ diameter of inhibition zone, MIC minimum inhibitory concentration, $I R$ inhibitory rate in 30 min, $M B C$ minimal bactericidal concentration

Especially the early exponential phase bacteria, they were killed completely in only $10 \mathrm{~min}$. The bacteria in stationary phase resulted in lysis after being treated with CHAP for $24 \mathrm{~h}$ (Fig. 3a).

\section{Bacterial biofilms assay}

The formation of biofilms of Staphylococcus aureus ATCC29213 was decreased with the increase of the concentration of CHAP (Fig. 3b). The $2 \times \mathrm{MIC}, 1 \times \mathrm{MIC}, 1 /$ $2 \times \mathrm{MIC}, 1 / 4 \times \mathrm{MIC}, 1 / 8 \times \mathrm{MIC}$ of $\mathrm{CHAP}$ could inhibited the formation of biofilms $(P<0.01)$ in $24 \mathrm{~h}$ and $2 \times \mathrm{MIC}$, $1 \times \mathrm{MIC}, 1 / 2 \times \mathrm{MIC}, 1 / 4 \times \mathrm{MIC}$ of CHAP could significantly decrease the formation of biofilms $(P<0.01)$ in $72 \mathrm{~h}$. Remarkably, in the $2 \times \mathrm{MIC}$ and $1 \times$ MIC groups, there were almost no biofilm formation.

\section{$\mathrm{NaCl}$ permeability assay}

As shown in Fig. $3 c$ and d, the values of $\mathrm{OD}_{600}$ of Escherichia coli ATCC 25922 and Staphylococcus aureus ATCC29213 cultures decreased with the increased concentration of $\mathrm{NaCl}$ solution and reached to their minimum values at concentration above $160 \mathrm{~g} \mathrm{~L}^{-1}$ and above $140 \mathrm{~g} \mathrm{~L}$ ${ }^{-1}$, respectively. By adding CHAP, the value of $\mathrm{OD}_{600}$ in both Escherichia coli ATCC 25922 and Staphylococcus aureus
ATCC29213 groups decreased to the lowest value at concentration of $\mathrm{NaCl}$ above $120 \mathrm{~g} \mathrm{~L}^{-1}$.

\section{Electron microscopy observations}

The morphology of the Escherichia coli ATCC 25922 and Staphylococcus aureus ATCC29213 investigated by SEM is shown in the Fig. 3. Compared to the smooth, straight and unbroken surface of the control cells (Fig. 4a and c), the strains treated with CHAP for $30 \mathrm{~min}$ appeared severely damaged (Fig. $3 \mathrm{~b}$ and $\mathrm{d}$ ). The TEM images further demonstrated that the bacterial surfaces were damaged by the effect of CHAP (Fig. 5a and c) compared with the control group (Fig. $4 \mathrm{~b}$ and d).

\section{Hemolytic assay and embryotoxicity assay}

The hemolysis of CHAP was $38.9 \%$ at the concentration of $360 \mu \mathrm{g} \mathrm{mL}{ }^{-1}$ which was more than 50 times higher than the MIC values for all the detected bacteria (see Additional file 2). And the embryotoxicity assay showed that even CHAP of $6 \times$ MIC dose against Escherichia coli ATCC25922 did not induce toxicity toward chicken embryos, that is, there was no dead or significant decrease of body weight compared to the control group $(P>0.05)$ (see Additional file 3). 


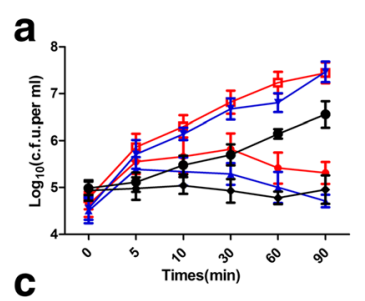

C
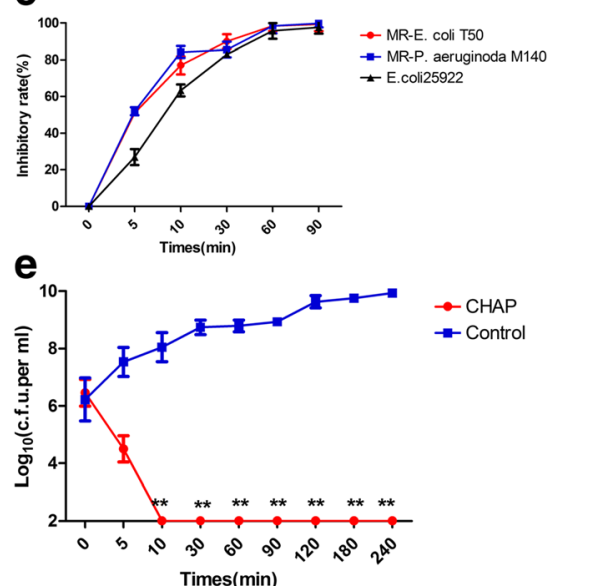

b

- MR-E. coli T50-CHAP $\rightarrow$ MR.P. coli T50-Control F MR-P. aeruginoda M140-Control -E.coli25922-CHAP

$\rightarrow$ E.coli25922-Control

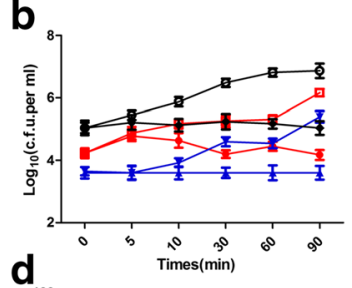

$\mathbf{d}_{100}$

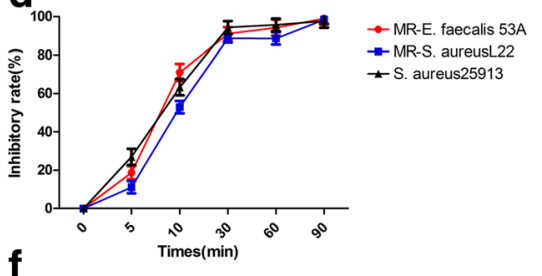

f

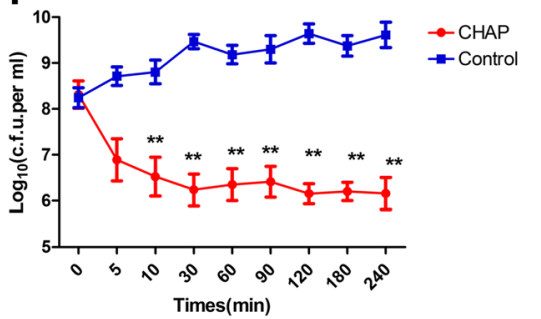

Fig. 2 a-b Time-dependent inhibitory curves of bacteria treated with CHAP and the bacteria treated with the solvent as control. a Gram-negative bacteria. $\mathbf{b}$ Gram-positive bacteria. c-d Time-dependent growth inhibitory rate curves of bacteria treated with CHAP and the bacteria treated with the solvent as control. c Gram-positive bacteria. $\mathbf{d}$ Gram-positive bacteria. e-f Time dependent bactericidal curves of Escherichia coli ATCC 25922 treated with CHAP and the bacteria treated with the solvent as control. e At early exponential phase. $\mathbf{f}$ At late exponential phase

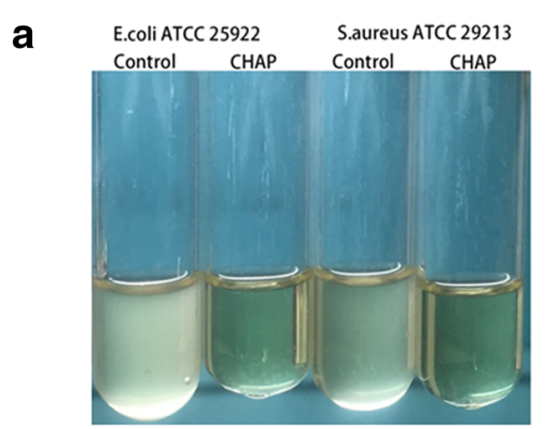

C

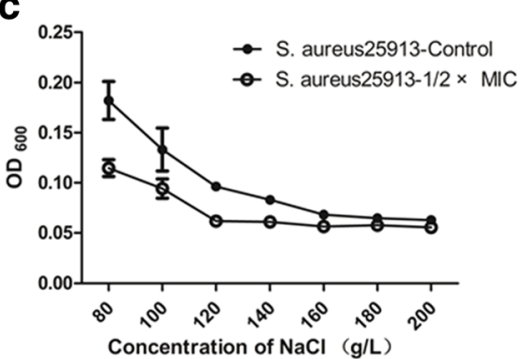

b

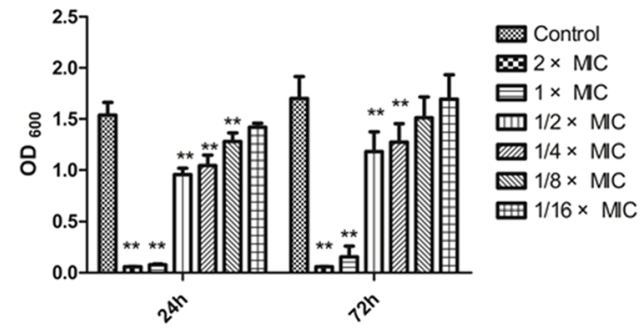

d

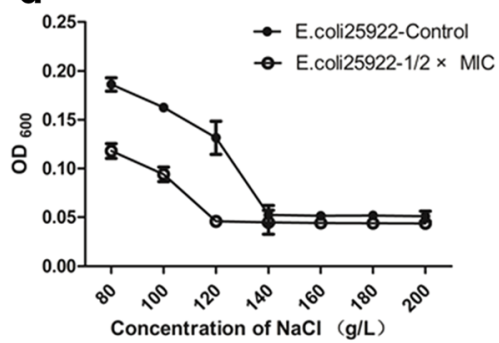

Fig. 3 a Bacteriolysis analysis. Bacteria in stationary phase treated with CHAP resulted in lysis with the solvent as control. b The inhibitory effect of CHAP on bacterial biofilm for $24 \mathrm{~h}$ and $72 \mathrm{~h}$. c-d The effect of CHAP on NaCl permeability of Escherichia coli ATCC 25922 and Staphylococcus aureus ATCC29213 

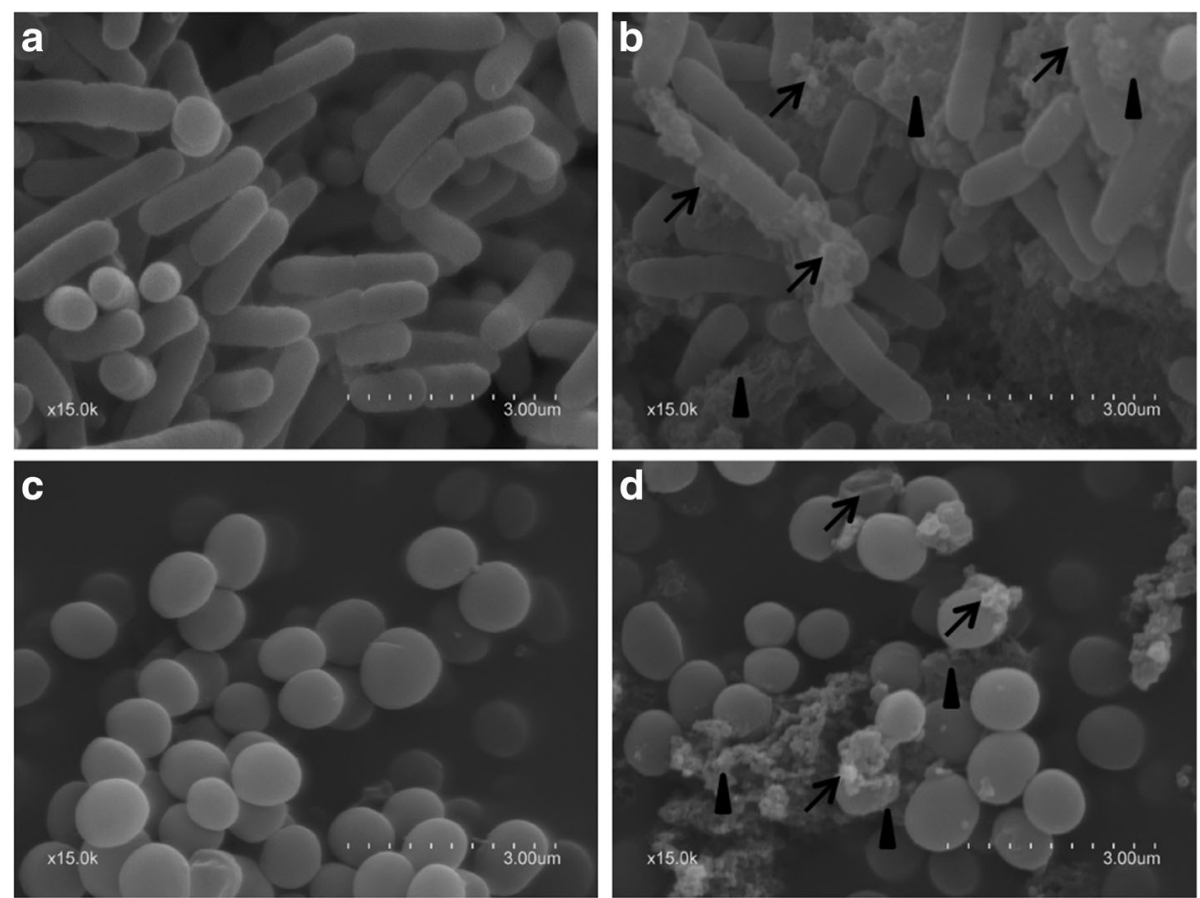

Fig. 4 The morphology of Escherichia coli ATCC 25922 and Staphylococcus aureus ATCC29213 were investigated by scanning electron microscopy. a-b The control group. c-d The Escherichia coli ATCC 25922 treated with CHAP. Viscous substances were adhering to almost all CHAP treated cells, which got large number of bacteria together (arrowheads); Some bacteria showed variable length, rough cell surfaces or globular protrusions on their surfaces, and even appeared to collapse (arrows)

\section{Stability in different temperatures and in $50 \%$ plasma}

The antimicrobial activity of CHAP did not decrease in different temperatures even when it was treated in $121^{\circ} \mathrm{C}$ for 30 min compared with CHAP stored in $4{ }^{\circ} \mathrm{C}(P>0.05)$ (Fig. 6a). It well proved that CHAP was capable of stability in various temperatures.

Compared with CHAP diluted in the solvent, the antimicrobial activity of CHAP showed no change in the treatment of chicken plasma and a slight but no significant decrease in treatment of rabbit plasma $(P>0.05)$ (Fig. 6b), which demonstrated that CHAP was of well stability in the plasma.

\section{Discussion}

Since the first anti-Streptococcus peptide was identified from the cow's milk [36], the enzyme strategy of isolating AMPs on a large scale has been a feasible method as Bolscher postulated [37]. Our lab isolated the peptides from the hemoglobin of chickens by using a simple and practical way and studied the antimicrobial activities against 19 bacterial strains, including 9 multidrugresistant bacteria. At the same time, the properties such as hemolytic activity, embryotoxicity and stability in different temperatures and plasma were detected, which laid a foundation for its further employment in agricultural production, public health and medication.
Antibiotics have been helping humans to fight against hazardous infections since Alexander Fleming discovered the first antibiotic, penicillin, in 1928 [38]. However, resistance to most antibiotics was discovered shortly after their applications. For example, penicillin resistance arose in 1946 just one year after its introduction to clinics [1]. The main target of most AMPs is cell membrane and there are several models for explaining the process such as barrel-stave pore model, thoroidal pore model and carpet model $[3,29,39]$, and it tends to be difficult for bacteria to totally change this basic structure to resist the effect of AMPs [3]. Given the unique antimicrobial mechanism of AMPs, it was not surprising that most AMPs induced little or no resistance [40, 41]. Although there are reports and doubts about the resistance of some peptides $[41,42]$, there is no report about the natural ones so far, which means the development of natural AMPs is high in potential.

In our study, both the antimicrobial and bactericide results showed that CHAP was capable of strong and rapid activities against various bacteria and even some multiresistant strains, implying its wider utility in the prevention and treatment of infectious agents, which was similar with the hemosidins reported before [16, 17]. By specifically analyzing the results above, there was no obvious difference between the antibacterial activity against Gram-negative bacteria and Gram-positive bacteria, even between the 

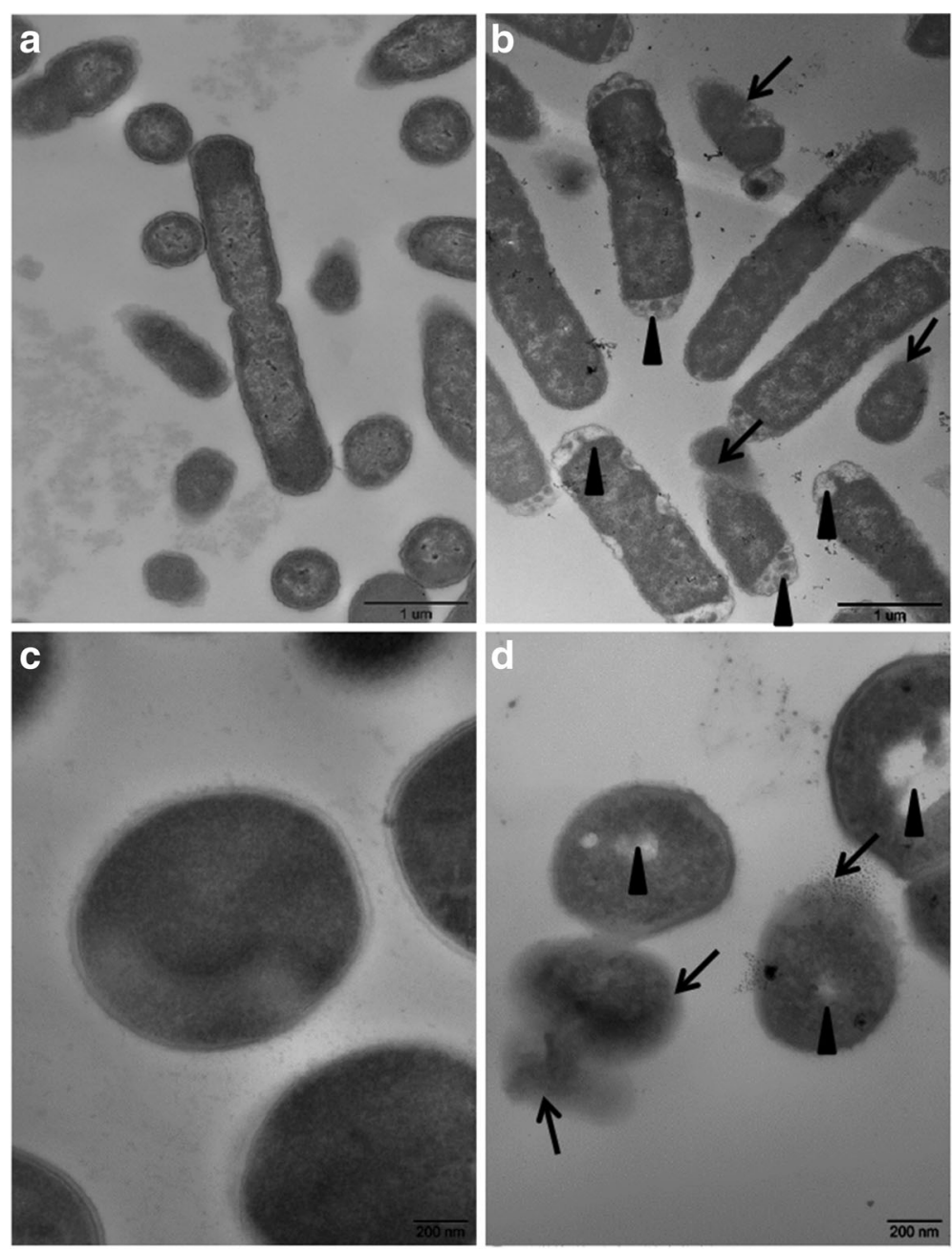

Fig. 5 The morphology of Escherichia coli ATCC 25922 Staphylococcus aureus ATCC29213 were investigated by transmission electron microscopy. a-b The control group. c-d The Escherichia coli ATCC 25922 treated with CHAP. Most of the bacteria were translucent and pores were evident on walls especially at the two terminals of each cell (arrowheads). There was some intracellular substance released from many bacteria (arrows).

standard strains and the multi-resistant strains, suggesting that the target of CHAP is the common component of bacteria such as the cell membrane like most AMPs reported before [29, 43]. The biofilm and the $\mathrm{NaCl}$ permeability results showed that CHAP could inhibit the formation of bacterial biofilms and change the permeability of some Gram-negative bacteria and Gram-positive bacteria to some extent. With the confirmation of the mechanism of most AMPs, the EM observations further revealed that CHAP could accumulate copious pathogens nearby and punch through their cell surfaces swiftly $[29,32]$.
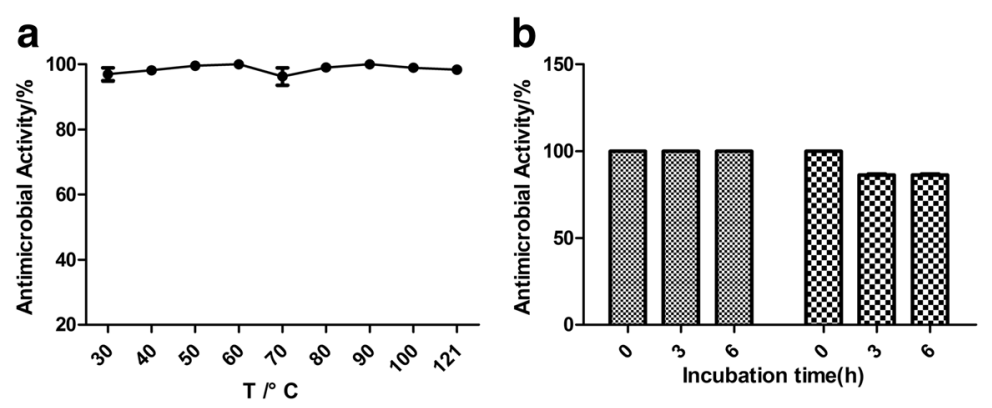

Fig. 6 The stability of CHAP. a The stability of the CHAP in different temperatures. b The stability of the CHAP in chicken and rabbit plasma 
However the specific mechanism needs to be further investigated.

As a double-edged sword, the unique mechanism of targeting cell membranes could also lead to the low selection of some AMPs [3]. Hence, toxicity especially hemolysis and safety problems, are constantly an obstacle to their final applications $[1,40,44]$. According to our study, CHAP demonstrated low hemolysis and embryotoxicity even at rather high concentrations, which further implied that there was relative high selectivity of CHAP between eukaryote cells and prokaryote cells.

Good stability also plays an important role in the application of any biological product. As for the AMPs, the substances such as ions and proteolytic enzymes in the serum may reduce their biological ability to a large extent $[29,45]$. In this study, CHAP kept high antimicrobial activity in two kinds of animal serum and different temperatures, suggesting its convenient application, transportation and storage.

\section{Conclusions}

In summary, this study firstly reported a practical method of isolating chicken hemosidins (CHAP) from the byproduct and even the pollutant of chicken-slaughtering industries. CHAP has an attractive antimicrobial and bactericidal ability with low hemolysis, low or none in toxicity and good temperature resistance and high stability in serum, which well accounts for their potential of expanding production and high development value in animal medication, breeding industry and environment protection.

\section{Additional files}

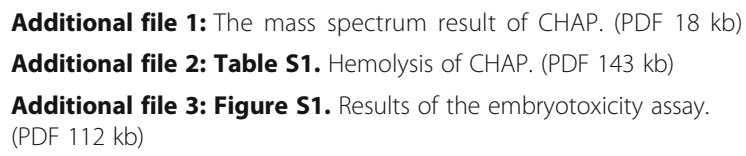

\section{Abbreviations}

AMPs: Antimicrobial peptides; BHI: Brain heart infusion; CFU: Colony-forming units; CHAP: Chicken hemoglobin antimicrobial peptides; CLSI: Clinical and Laboratory Standards Institute; CVCC: China Veterinary Culture Collection Center; LB: Luria-Bertani; MBC: Minimal bactericidal concentration; MH: Mueller- Hinto; MIC: Minimum inhibitory concentration; OD: Optical density; SEM: Scanning electron microscopy; TEM: Transmission electron microscopy; TSB: Trypticase soy broth

\section{Acknowledgements}

We would like to thank the National Natural Science Foundation of China, Beijing Key Laboratory of Detection Technology for animal Food safety of the College of Veterinary Medicine, China Agricultural University, Beijing Protein Institute and Beijing Huadu CO.

\section{Funding}

This study was funded by the National Natural Science Foundation of China (31072110, 31272515).

\section{Availability of data and materials}

All data supporting our findings are included within the article and supplemental files

\section{Authors' contributions}

RShe conceived and supervised the study; HF and RShe designed experiments; HF, WQ, SS, YZ, YY, MZ and FD performed experiments; HF, WQ, SS analyzed and interpreted the data; HF wrote the manuscript; RShe, MHS and RShi made manuscript revisions. All authors read and approved the final manuscript.

\section{Competing interests}

The authors declare that they have no competing interest.

\section{Consent for publication}

Not applicable.

\section{Ethics approval and consent to participate}

All the animal experiments were approved by the Animal Care and Use Committee of China Agricultural University (permit number: 20150115-058). We followed the guidelines of the China Agricultural University Animal Care and Use Committee when handling the experimental animals during this study (The certificate of Beijing Laboratory Animal employee, ID: 114120800171).

\section{Author details}

${ }^{1}$ Department of Veterinary Pathology and Public Health, Key Laboratory of Zoonosis of Ministry of Agriculture College of Veterinary Medicine, China Agricultural University, Beijing 100193, China. ${ }^{2}$ Beijing Huadu Broiler Corporations, Beijing 102211, China.

Received: 11 July 2016 Accepted: 25 November 2016

Published online: 05 December 2016

\section{References}

1. Lewis K. Platforms for antibiotic discovery. Nat Rev Drug Discov. 2013;12(5): 371-87.

2. Ling LL, Schneider T, Peoples AJ, Spoering AL, Engels I, Conlon BP, Mueller A, Schaberle TF, Hughes DE, Epstein S, et al. A new antibiotic kills pathogens without detectable resistance. Nature. 2015;517(7535):455-9.

3. Zasloff M. Antimicrobial peptides of multicellular organisms. Nature. 2002; 415(6870):389-95.

4. Nizet V. Antimicrobial peptide resistance mechanisms of human bacterial pathogens. Curr Issues Mol Biol. 2006;8(1):11-26.

5. Gallo RL. The birth of innate immunity. Exp Dermatol. 2013;22(8):517.

6. Ginsburg I, Koren E. Are cationic antimicrobial peptides also 'double-edged swords'? Expert Rev Anti Infect Ther. 2008;6(4):453-62.

7. Basu D, Kulkarni R. Overview of blood components and their preparation. Indian J Anaesth. 2014;58(5):529-37.

8. Drago L, Bortolin M, Vassena C, Taschieri S, Del Fabbro M. Antimicrobial activity of pure platelet-rich plasma against microorganisms isolated from oral cavity. BMC Microbiol. 2013;13:47.

9. Merchant ME, Leger N, Jerkins E, Mills K, Pallansch MB, Paulman RL, Ptak RG. Broad spectrum antimicrobial activity of leukocyte extracts from the American alligator (Alligator mississippiensis). Vet Immunol Immunopathol. 2006;110(3-4):221-8.

10. Hamidi M, Tajerzadeh H. Carrier erythrocytes: an overview. Drug Deliv. 2003; 10(1):9-20.

11. Brantl V, Gramsch C, Lottspeich F, Mertz R, Jaeger KH, Herz A. Novel opioid peptides derived from hemoglobin: hemorphins. Eur J Pharmacol. 1986; 125(2):309-10.

12. Zhao QY, Piot JM, Gautier V, Cottenceau G. Isolation and characterization of a bacterial growth-stimulating peptide from a peptic bovine hemoglobin hydrolysate. Appl Microbiol Biotechnol. 1996;45(6):778-84.

13. Karelin AA, Philippova MM, Ivanov VT. Proteolytic degradation of hemoglobin in erythrocytes leads to biologically active peptides. Peptides. 1995;16(4):693-7.

14. Fogaca AC, da Silva Jr PI, Miranda MT, Bianchi AG, Miranda A, Ribolla PE, Daffre S. Antimicrobial activity of a bovine hemoglobin fragment in the tick Boophilus microplus. J Biol Chem. 1999;274(36):25330-4.

15. Alvarez C, Rendueles M, Diaz M. Production of porcine hemoglobin peptides at moderate temperature and medium pressure under a nitrogen stream. Functional and antioxidant properties. J Agric Food Chem. 2012; 60(22):5636-43. 
16. Mak P, Wojcik K, Silberring J, Dubin A. Antimicrobial peptides derived from heme containing proteins: hemocidins. Antonie Van Leeuwenhoek. 2000;77(3):197-207.

17. Liepke C, Baxmann S, Heine C, Breithaupt N, Standker L, Forssmann WG. Human hemoglobin-derived peptides exhibit antimicrobial activity: a class of host defense peptides. J Chromatogr B Analyt Technol Biomed Life Sci. 2003;791(1-2):345-56.

18. Patgaonkar M, Aranha C, Bhonde G, Reddy KV. Identification and characterization of anti-microbial peptides from rabbit vaginal fluid. Vet Immunol Immunopathol. 2011;139(2-4):176-86.

19. Srihongthong S, Pakdeesuwan A, Daduang S, Araki T, Dhiravisit A, Thammasirirak S. Complete amino acid sequence of globin chains and biological activity of fragmented crocodile hemoglobin (Crocodylus siamensis). Protein J. 2012;31(6):466-76.

20. Fernandes JM, Smith VJ. Partial purification of antibacterial proteinaceous factors from erythrocytes of Oncorhynchus mykiss. Fish Shellfish Immunol. 2004;16(1):1-9.

21. Gambacurta A, Piro MC, Ascoli F. Cooperative homodimeric hemoglobin from Scapharca inaequivalvis. CDNA cloning and expression of the fully functional protein in E. coli. FEBS Lett. 1993;330(1):90-4.

22. Mak P, Wojcik K, Wicherek L, Suder P, Dubin A. Antibacterial hemoglobin peptides in human menstrual blood. Peptides. 2004:25(11):1839-47.

23. Nedjar-Arroume N, Dubois-Delval V, Adje EY, Traisnel J, Krier F, Mary P, Kouach M, Briand G, Guillochon D. Bovine hemoglobin: an attractive source of antibacterial peptides. Peptides. 2008;29(6):969-77.

24. Adje EY, Balti R, Kouach M, Dhulster P, Guillochon D, Nedjar-Arroume N. Obtaining antimicrobial peptides by controlled peptic hydrolysis of bovine hemoglobin. Int J Biol Macromol. 2011;49(2):143-53.

25. Kundu P, Debsarkar A, Mukherjee S. Treatment of slaughter house wastewater in a sequencing batch reactor: performance evaluation and biodegradation kinetics. Biomed Res Int. 2013;2013:134872.

26. Zhang Y, She R, Liu T, Wengui LI, Jia J. Studies on isolation, purification and antibacterial activities of antibacterial peptides in swine blood. Science \& Technology Review (China). 2008;26(2):33-7.

27. Bao H, She R, Liu T, Zhang Y, Peng KS, Luo D, Yue Z, Ding Y, Hu Y, Liu W, et al. Effects of pig antibacterial peptides on growth performance and intestine mucosal immune of broiler chickens. Poult Sci. 2009:88(2):291-7.

28. Schagger $H$, von Jagow $G$. Tricine-sodium dodecyl sulfate-polyacrylamide gel electrophoresis for the separation of proteins in the range from 1 to 100 kDa. Anal Biochem. 1987;166(2):368-79.

29. Hou Z, Lu J, Fang C, Zhou Y, Bai H, Zhang X, Xue X, Chen Y, Luo X. Underlying mechanism of in vivo and in vitro activity of $C$-terminalamidated thanatin against clinical isolates of extended-spectrum betalactamase-producing Escherichia coli. J Infect Dis. 2011;203(2):273-82.

30. Nair S, Desai S, Poonacha N, Vipra A, Sharma U. Antibiofilm activity and synergistic inhibition of S. aureus biofilms by bactericidal protein P128 in combination with antibiotics. Antimicrob Agents Chemother. 2016;60(12):7280-9.

31. De Oliveira MV, Intorne AC, Vespoli Lde S, Madureira HC, Leandro MR, Pereira TN, Olivares FL, Berbert-Molina MA, De Souza Filho GA. Differential effects of salinity and osmotic stress on the plant growth-promoting bacterium Gluconacetobacter diazotrophicus PAL5. Arch Microbiol. 2016;198(3):287-94.

32. Shi J, Ross CR, Chengappa MM, Sylte MJ, McVey DS, Blecha F. Antibacteria activity of a synthetic peptide (PR-26) derived from PR-39, a prolinearginine-rich neutrophil antimicrobial peptide. Antimicrob Agents Chemother. 1996;40(1):115-21.

33. Cao L, Dai C, Li Z, Fan Z, Song Y, Wu Y, Cao Z, Li W. Antibacterial activity and mechanism of a scorpion venom peptide derivative in vitro and in vivo. PLoS One. 2012;7(7):e40135.

34. Ding Y, Zou J, Li Z, Tian J, Abdelalim S, Du F, She R, Wang D, Tan C, Wang $\mathrm{H}$, et al. Study of histopathological and molecular changes of rat kidney under simulated weightlessness and resistance training protective effect. PLoS One. 2011;6(5):e20008.

35. Stark M, Liu LP, Deber CM. Cationic hydrophobic peptides with antimicrobial activity. Antimicrob Agents Chemother. 2002;46(11):3585-90.

36. Jones FS, Simms HS. The bacterial growth inhibitor (lactenin) of milk : i. the preparation in concentrated form. J Exp Med. 1930;51(2):327-39.

37. Bolscher JG, van der Kraan MI, Nazmi K, Kalay H, Grun CH, Van't Hof W, Veerman EC, Nieuw Amerongen AV. A one-enzyme strategy to release an antimicrobial peptide from the LFampin-domain of bovine lactoferrin. Peptides. 2006;27(1):1-9.

38. Fleming AG. Responsibilities and Opportunities of the Private Practitioner in Preventive Medicine. Can Med Assoc J. 1929;20(1):11-3.
39. Pompilio A, Crocetta V, Scocchi M, Pomponio S, Di Vincenzo V, Mardirossian M, Gherardi G, Fiscarelli E, Dicuonzo G, Gennaro R, et al. Potential novel therapeutic strategies in cystic fibrosis: antimicrobial and anti-biofilm activity of natural and designed alpha-helical peptides against Staphylococcus aureus, Pseudomonas aeruginosa, and Stenotrophomonas maltophilia. BMC Microbiol. 2012;12:145.

40. Hancock RE, Sahl HG. Antimicrobial and host-defense peptides as new antiinfective therapeutic strategies. Nat Biotechnol. 2006;24(12):1551-7.

41. Bell G, Gouyon PH. Arming the enemy: the evolution of resistance to selfproteins. Microbiology. 2003;149(Pt 6):1367-75.

42. Habets MG, Brockhurst MA. Therapeutic antimicrobial peptides may compromise natural immunity. Biol Lett. 2012;8(3):416-8.

43. Melo MN, Ferre R, Castanho MA. Antimicrobial peptides: linking partition, activity and high membrane-bound concentrations. Nat Rev Microbiol. 2009:7(3):245-50.

44. Marr AK, Gooderham WJ, Hancock RE. Antibacterial peptides for therapeutic use: obstacles and realistic outlook. Curr Opin Pharmacol. 2006;6(5):468-72.

45. Bowdish DM, Davidson DJ, Lau YE, Lee K, Scott MG, Hancock RE. Impact of LL-37 on anti-infective immunity. J Leukoc Biol. 2005;77(4):451-9.

\section{Submit your next manuscript to BioMed Central and we will help you at every step:}

- We accept pre-submission inquiries

- Our selector tool helps you to find the most relevant journal

- We provide round the clock customer support

- Convenient online submission

- Thorough peer review

- Inclusion in PubMed and all major indexing services

- Maximum visibility for your research

Submit your manuscript at www.biomedcentral.com/submit
) Biomed Central 